\title{
ॠUSGS
}

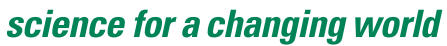

\section{Landslides Triggered by the 0ctober 8, 2005, Pakistan Earthquake and Associated Landslide-Dammed Reservoirs}

By Edwin L. Harp and Anthony J. Crone

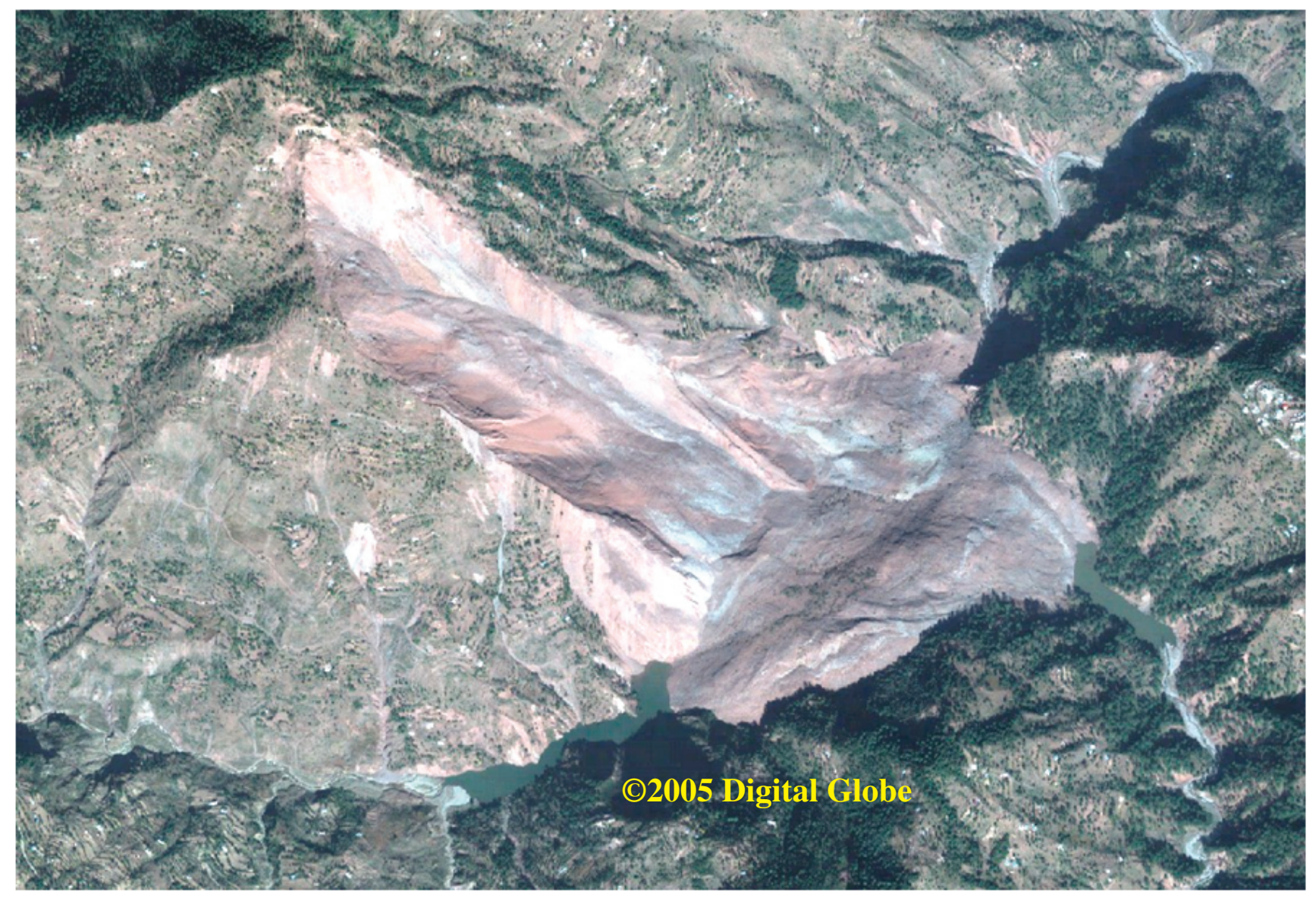

Open-File Report 2006-1052 


\section{U.S. Department of the Interior \\ P. Lynn Scarlett, Acting Secretary}

\section{U.S. Geological Survey \\ P. Patrick Leahy, Acting Director}

U.S. Geological Survey, Reston, Virginia 2006

For product and ordering information:

World Wide Web: http://www.usgs.gov/pubprod

Telephone: 1-888-ASK-USGS

For more information on the USGS - the Federal source for science about the Earth, its natural and living resources, natural hazards, and the environment:

World Wide Web: http://www.usgs.gov

Telephone: 1-888-ASK-USGS

Harp, Edwin L., and Crone, Anthony J., 2006, Landslides Triggered by the October 8, 2005, Pakistan Earthquake and Associated Landslide-Dammed Reservoirs: U.S. Geological Survey Open-file Report 2006-1052, 13 p.

Any use of trade, firm, or product names is for descriptive purposes only and does not imply endorsement by the U.S. Government.

Although this report is in the public domain, permission must be secured from the individual copyright owners to reproduce any copyrighted material contained within this report. 


\section{Contents}

Abstract town.

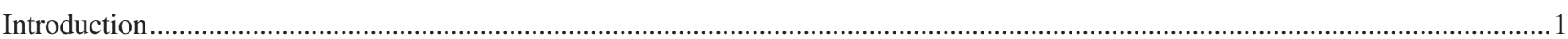

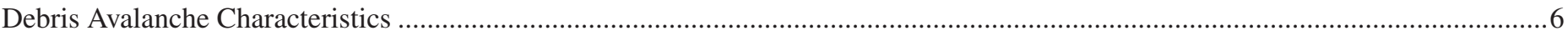

Mitigation of Flood Hazard Posed by the Landslide Dams ............................................................................................ 6

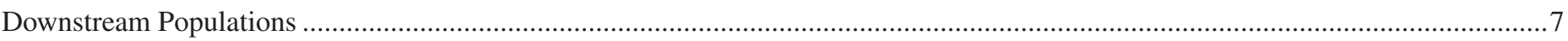

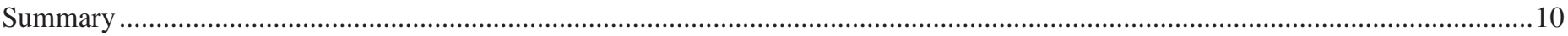

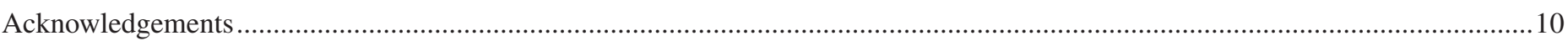

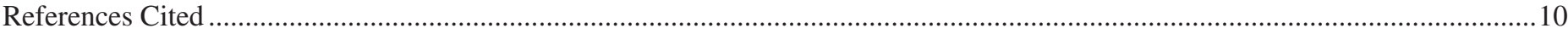

\section{Figures}

1. (A) Location map (colored shaded relief) showing the location of the Hattian Bala landslide in Pakistan .....

(B) Location map (colored shaded relief) showing the location of the Kashmir earthquake epicenter and the Hattian Bala landslide. (Maps from Google Earth)

2. Views of the Hattian Bala debris avalanche. (A) Near-vertical view of the Hattian Bala debris avalanche and the two lakes impounded by the landslide debris in the Karli and Tang valleys. (Photograph from DigitalGlobe Quickbird II Natural Color, October 27, 2005). Debris traveled approximately 1.5 kilometers from the crest of Dana Hill to Karli Valley. Secondary slump is indicated by arrows. Area of concentrated fractures is noted in lower left of the photograph. (B) Oblique aerial view of the Hattian Bala debris avalanche showing the avalanche scarp, travel path, and debris, the lake in the Karli drainage, a secondary slump at the right side of the photograph (arrow), and area of fractures shown in figure 5 (arrow at left of photograph) .............. 4

3. Oblique aerial view of the debris impounding the lake in the Karli stream drainage (Photograph courtesy of USAID) .................5

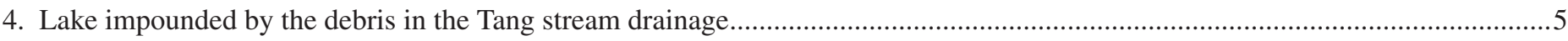

5. Oblique aerial view of slopes above the reservoir in the Karli stream drainage with numerous fractures (lower left in photograph) extending through the terrain parallel to the slope direction and to the strike of bedding ..................................... 6

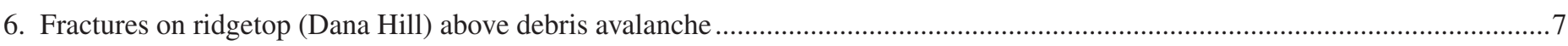

7. Ground view of debris avalanche and Karli stream debris dam with arrow pointing to low point at the crest where a spillway is to be excavated.

8. View northeast downvalley from crest of the Karli stream landslide dam where Pakistan military engineers plan to construct a spillway in the debris. Note the depression in the foreground where some of the excavated debris may be deposited.......

9. Northward aerial view of village of Hattian showing bridge on main highway to India and other permanent and temporary dwellings near stream level of the landslide-dammed Karli tributary to the Jhelum River....

10. Aerial view of tributary stream drainage near Hattian. Location of tent camp in middle ground is on a smooth ramp just above the tributary stream (arrows) whose channel is curving to the left. This area is likely to be subject to severe runup, or superelevation, of floodflow immediately following a potential breach of the Karli stream landslide dam .... 


\title{
Landslides Triggered by the October 8, 2005, Pakistan Earthquake and Associated Landslide-Dammed Reservoirs
}

\author{
By Edwin L. Harp and Anthony J. Crone
}

\section{Abstract}

The October 8, 2005, Kashmir earthquake (M 7.6) triggered several thousand landslides, mainly rock falls and rock slides, in the epicentral area near the cities of Muzafarrabad and Balakot, Pakistan. Most of these were shallow, coalescing rock slides emanating from highly sheared and deformed limestone and dolomite of the Precambrian Muzafarrabad Formation. The largest landslide triggered by the earthquake is located approximately 32 kilometers southeast of Muzafarrabad in a tributary valley of the Jhelum River. This landslide is a debris avalanche of approximately 80 million cubic meters volume within the Miocene Murree Formation consisting of mixed sandstone, mudstone, shale, and limestone. The avalanche buried the village of Dandbeh and resulted in approximately 1,000 fatalities, according to local residents. The avalanche deposit traveled approximately 1.5 kilometers downslope and 300 meters or more up the opposite slope in the adjacent Karli stream drainage and also extended into the Tang stream drainage where the Tang stream joins the Karli drainage. The landslide mass has impounded two lakes within the blocked drainages. The lake in the Karli drainage was approximately 800 meters long and 20 meters deep as of December 19, 2005. The lake in the Tang drainage was approximately 400 meters long and 10 meters deep as of this same date. Downstream populations are at risk from possible flash flooding when these debris dams are overtopped by the reservoir water. The closest village, Hattian, is 2.8 kilometers downstream at the junction of the Jhelum River and the landslide-dammed Karli tributary. Other populations along the Jhelum River may also be at risk. Pakistan military engineers are preparing to construct a spillway within the landslide deposits to lessen the severity of the flood if the lake in the Karli stream drainage breaches the landslide dam catastrophically.

\section{Introduction}

Several thousand landslides, most of which are shallow rock falls and rock slides were triggered in the epicentral region of the Kashmir earthquake near the cities of Muzafarrabad and Balakot and along the valleys of the Jhelum, Neelum, and Khagan Rivers
(Schneider, 2006). Preliminary studies by Sato and others (2006) using SPOT 5 imagery show concentrations of landslides along the Tanda and Muzafarrabad faults of the Main Frontal Thrust Zone of the pre-Himalaya. The most highly concentrated rock falls and rock slides, located along the Muzafarrabad section of the Main Frontal Thrust Zone, were from the highly fractured and deformed limestones and dolomites of the Precambrian Muzafarrabad Formation.

Eighty million cubic meters of rock and soil dislodged from a mountainside in the Kashmir Range by the earthquake traveled approximately $1.5 \mathrm{~km}$ downslope as a debris avalanche (landslide nomenclature according to Varnes, 1978) damming two tributaries of the Jhelum River. The Hattian Bala avalanche, located approximately $32 \mathrm{~km}$ southeast of Muzafarrabad (figs. $1 \mathrm{~A}$ and $1 \mathrm{~B})$, filled the valley of the Karli stream for $1.3 \mathrm{~km}$ and also blocked the drainage of the Tang stream valley at its intersection with the Karli stream. The avalanche debris filled the Karli drainage to a depth of about $130 \mathrm{~m}$ above the valley axis (figs. 2A and 2B). Two reservoirs have been impounded upstream from the landslide dam. The larger reservoir is in the Karli stream drainage and is about $20 \mathrm{~m}$ deep and $800 \mathrm{~m}$ long as of December 19, 2005 (fig. 3). Its water level as of this date is at 1,267.55-m elevation with slightly more than $100 \mathrm{~m}$ to rise before it will overtop the landslide debris (established by recent survey by Pakistan Military Engineers completed December 18, 2005). The smaller reservoir in the Tang stream drainage was approximately $10 \mathrm{~m}$ deep and $400 \mathrm{~m}$ long as of December 19, 2005 (fig. 4). This reservoir had only $22 \mathrm{~m}$ to rise before it overtopped the landslide debris blocking its path.

Downstream from the landslide dam, the river channel is steep and tortuous. The village of Hattian is $2.8 \mathrm{~km}$ downstream from the landslide dam at the junction with the Jhelum River, and numerous dwellings, including tents, are near river level. Scattered dwellings exist along the Jhelum River at, or near, river level between Hattian and Muzafarrabad. In several places, relocated people in tent villages are located near the flood plain of the river and are possibly at risk should the landslide dam breach catastrophically. 


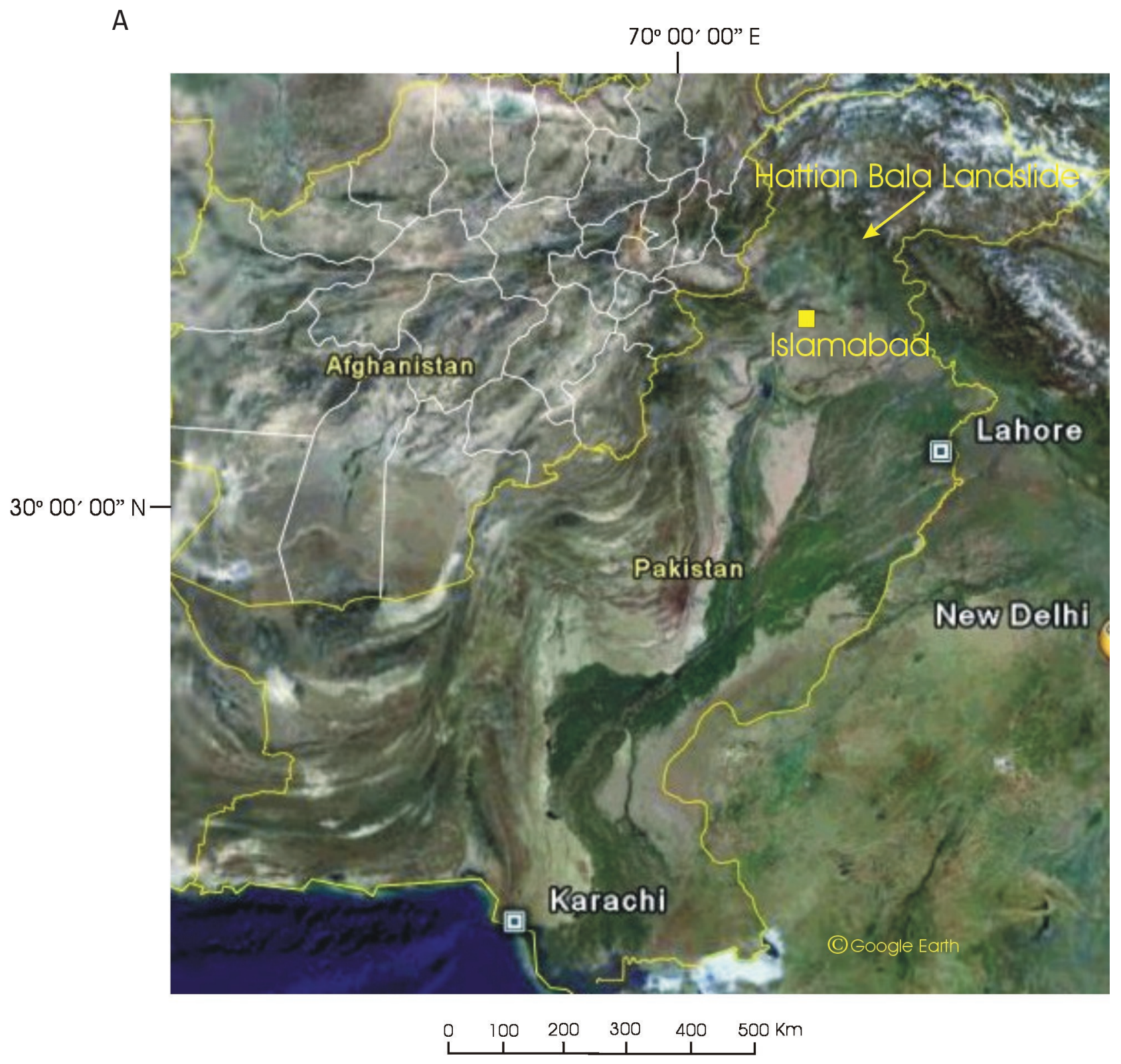

Figure 1. (A) Location map (colored shaded relief) showing the location of the Hattian Bala landslide in Pakistan. 


\section{B}

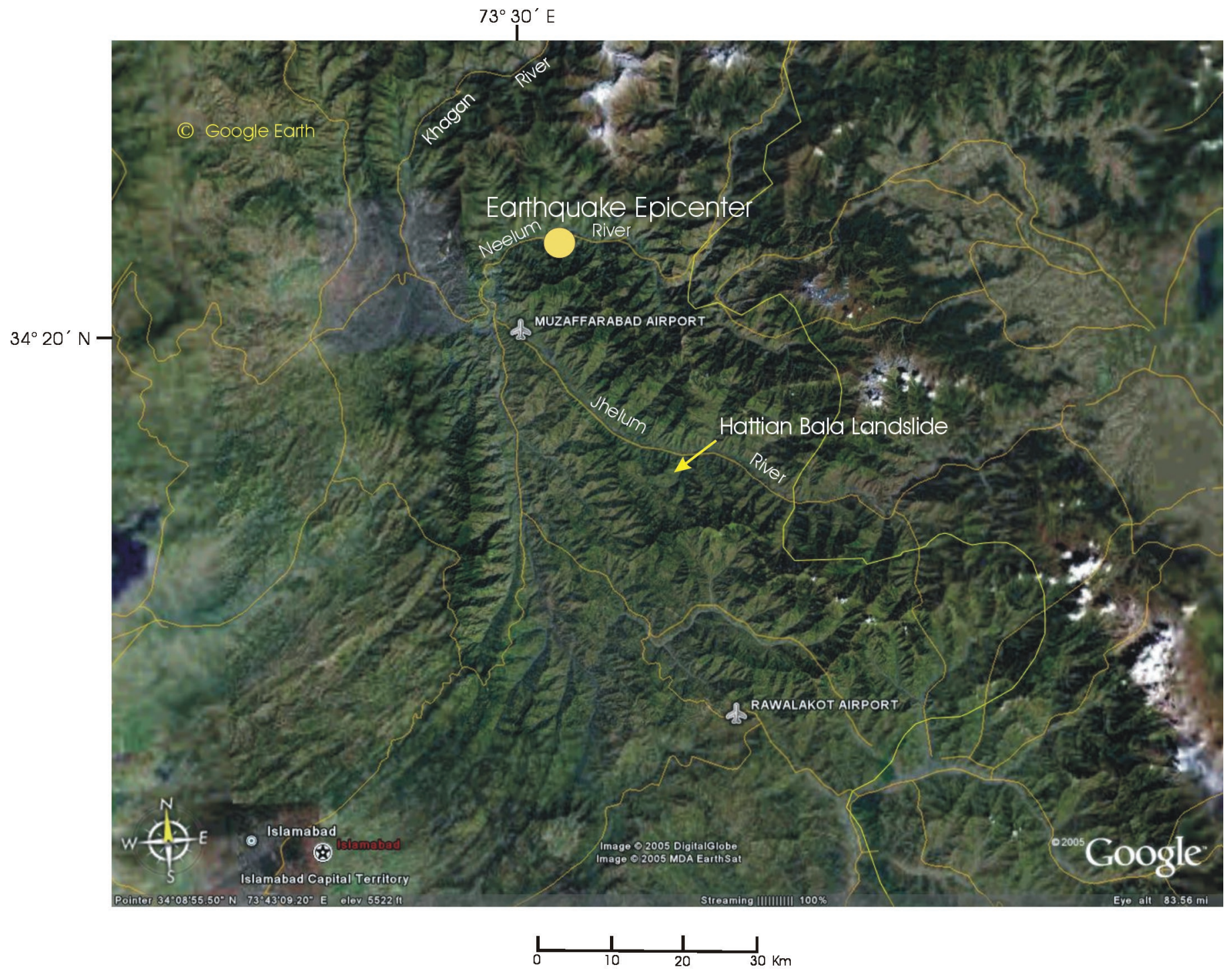

Figure 1. (B) Location map (colored shaded relief) showing the location of the Kashmir earthquake epicenter and the Hattian Bala landslide. (Maps from Google Earth) 
A
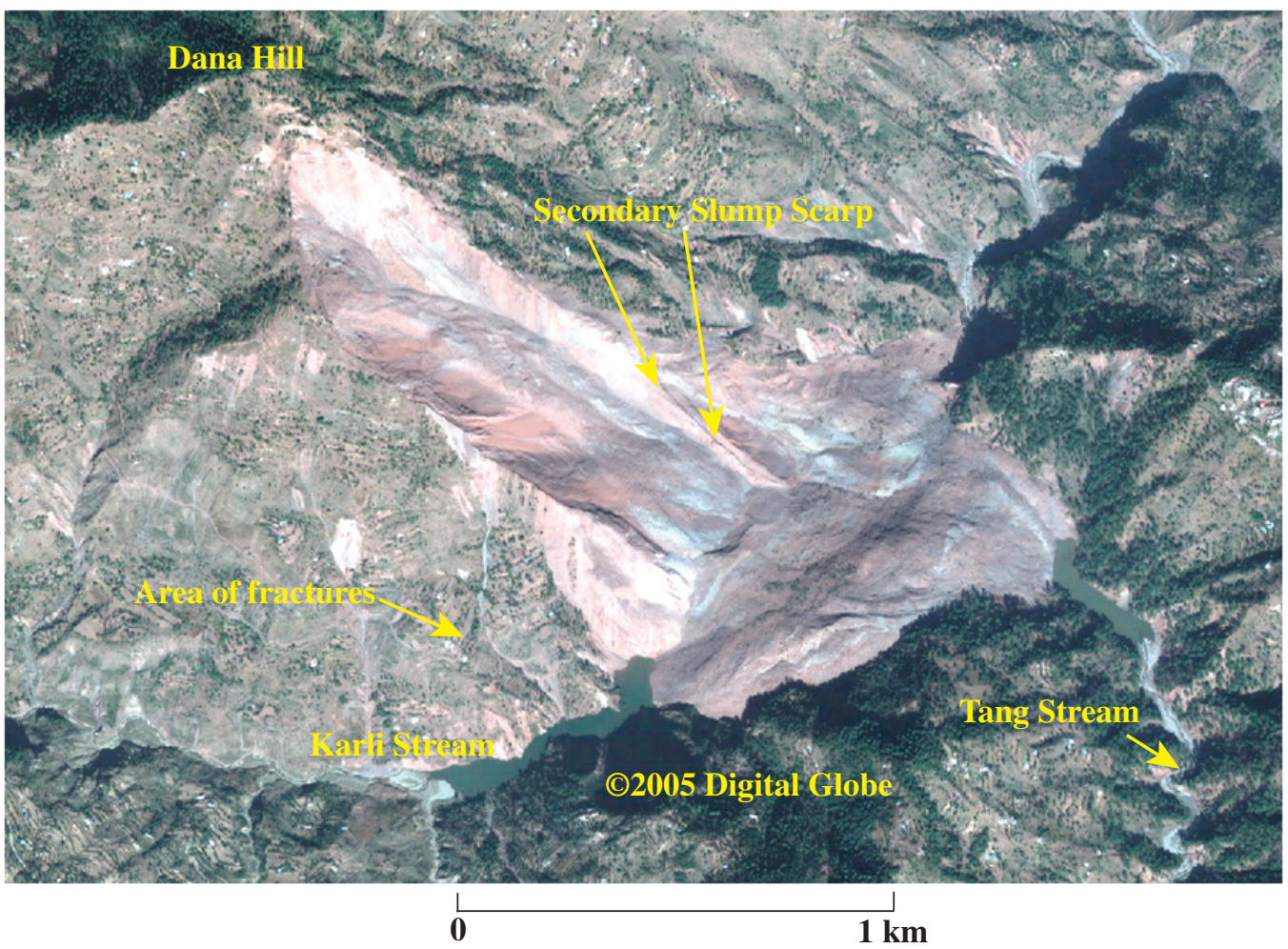

B

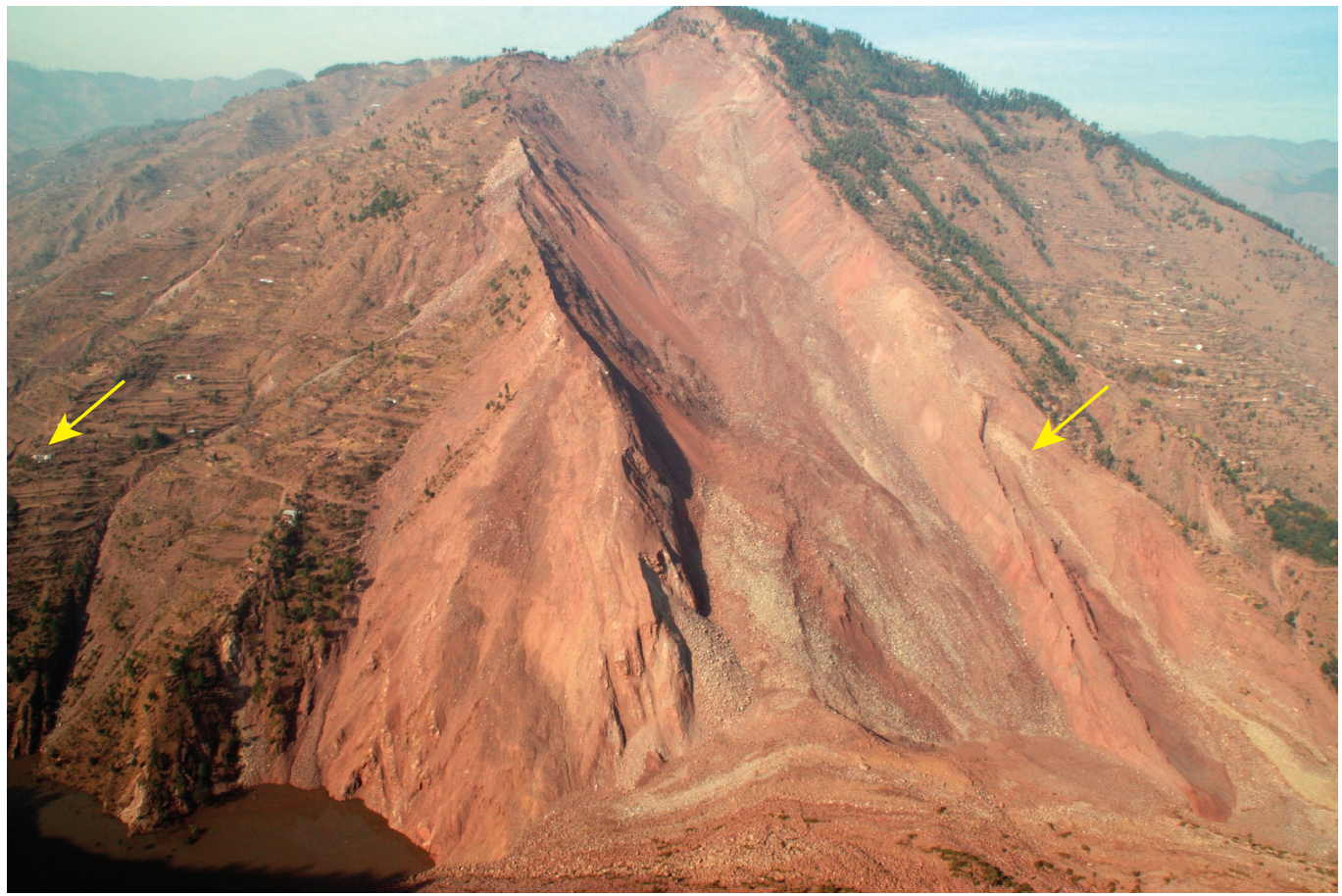

Figure 2. Views of the Hattian Bala debris avalanche. (A) Near-vertical view of the Hattian Bala debris avalanche and the two lakes impounded by the landslide debris in the Karli and Tang valleys. (Photograph from DigitalGlobe Quickbird II Natural Color, October 27, 2005). Debris traveled approximately 1.5 kilometers from the crest of Dana Hill to Karli Valley. Secondary slump is indicated by arrows. Area of concentrated fractures is noted in lower left of the photograph. (B) Oblique aerial view of the Hattian Bala debris avalanche showing the avalanche scarp, travel path and debris, the lake in the Karli drainage, a secondary slump at the right side of the photograph (arrow), and area of fractures shown in figure 5 (arrow at left of photograph). 


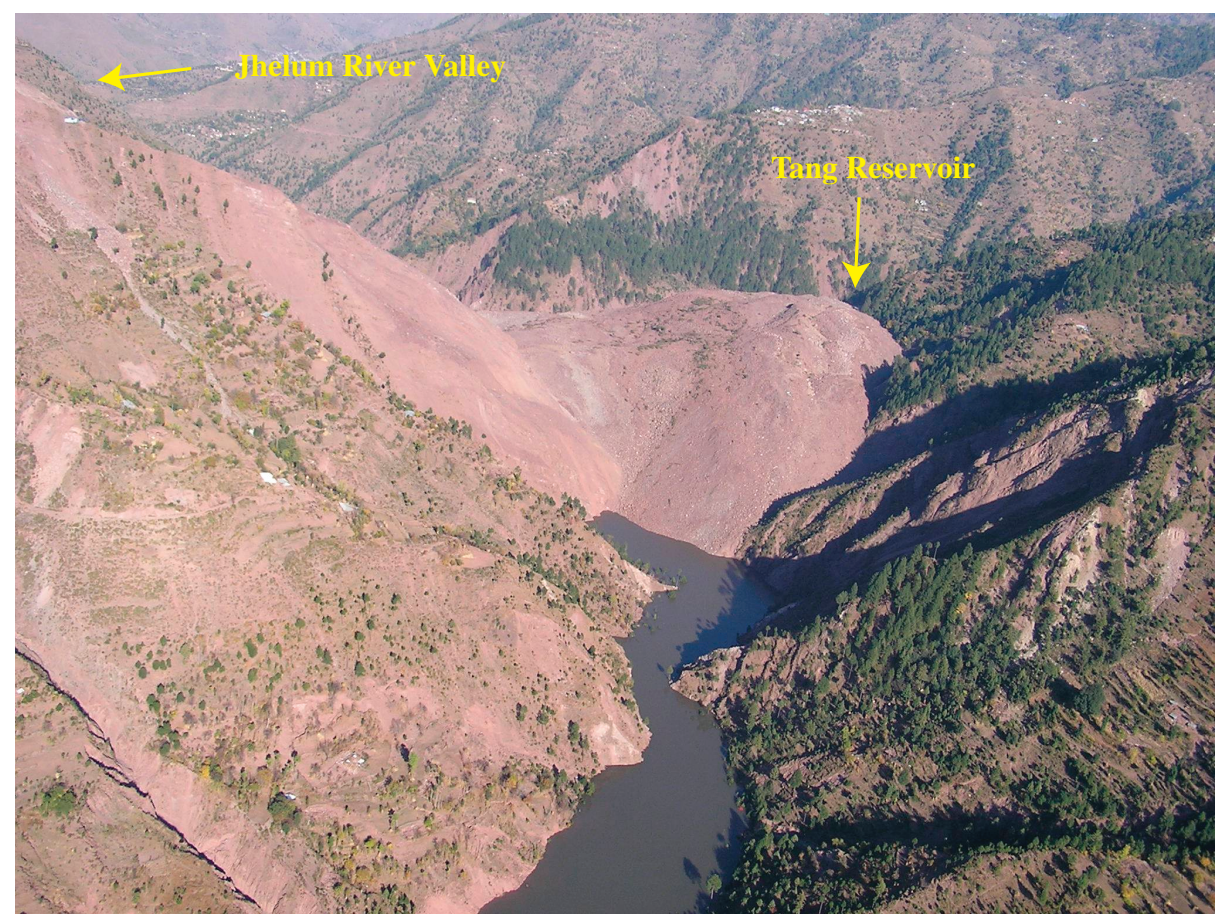

Figure 3. Oblique aerial view of the debris impounding the lake in the Karli stream drainage (Photograph courtesy of USAID).

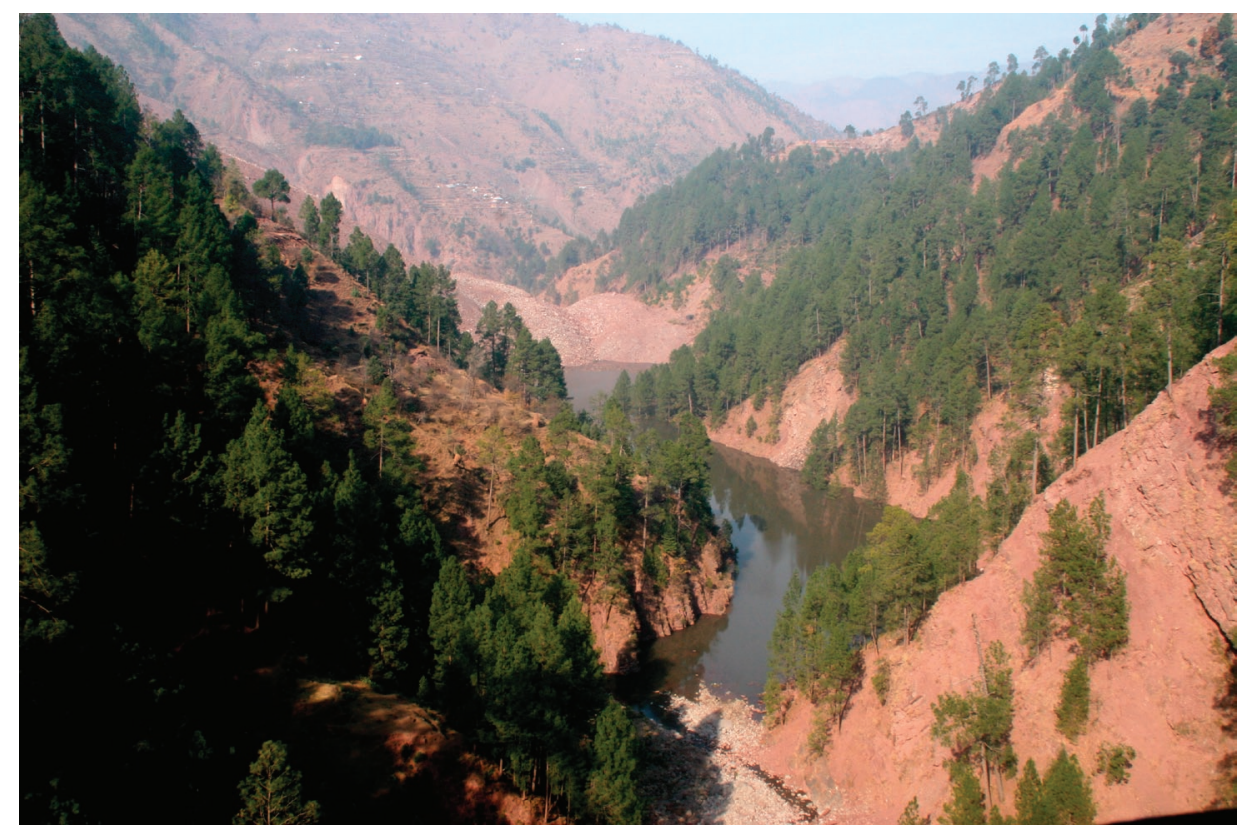

Figure 4. Lake impounded by the debris in the Tang stream drainage. 


\section{Debris Avalanche Characteristics}

The source of the avalanche extends to an elevation of 1,948 $m$ near the crest of a mountain (local name, Dana Hill) northwest of the intersection of the Karli and Tang drainages. The landslide path from headscarp to toe is approximately $2.0 \mathrm{~km}$ long with a fairly constant width of about $0.5 \mathrm{~km}$. Judging from the heights of the lateral shear surfaces, the thickness of the landslide mass is 70-90 m. The avalanche material is reddish sandstone, mudstone, and shale of the Miocene Murree Formation (Calkins and others, 1975) with a minor fraction of limestone. The avalanche debris ranges in size from clay-size fragments to boulders of up to 7 or $8 \mathrm{~m}$ in diameter. The avalanche debris in the valley bottom is prism-shaped in cross section with an irregular surface that roughly reflects the valley topography. The debris has traveled $300 \mathrm{~m}$ beyond the valley bottom and has carried up the opposite slope and over a ridge 70-80 $\mathrm{m}$ high where it blocks the drainage of the Tang stream.

Several other slumps and rock slides are present along the margins of the avalanche. At its lower left shear surface (looking downslope), a secondary slump has formed in the ridge forming the left margin of the slide (fig. 2B). Roughly triangular in shape, this slump is about $300 \mathrm{~m}$ from crown to toe with a headscarp approximately $15 \mathrm{~m}$ high. Several secondary rock slides issue from the steep right margin of the avalanche (fig. 2B).

Numerous fractures occur in bedrock at the avalanche margins. Fractures bounding incipient slumps are present along both lateral margins of the landslide path as well as at the headscarp area. Many fractures are present immediately to the southwest of the avalanche path. This area just above the reservoir to the top of the mountainside is laced with fractures that may be part of an incipient slump mass and (or) a network of fractures generated from the shaking alone (fig. 5). Most of these fractures seem to be parallel to the strike of the bedding.
The top of the mountain on which the avalanche occurred and several ridges near the top also are covered with fractures that are concentrated at the ridge crests and the summit (fig. 6). These fractures probably are associated with increased levels of shaking due to topographic amplification of the ground shaking.

Although the landslide debris includes numerous large boulders, much of the debris consists of sand, silt, and clay-sized particles. These fine materials are easily eroded and will offer little resistance to stream downcutting once the reservoir water overtops the landslide dam. The erosion of the landslide dam likely will be rapid, possibly culminating in sudden failure of the dam and release of the reservoir water. A flash flood could then ensue and proceed rapidly downstream. The village of Hattian is $2.8 \mathrm{~km}$ downstream from the dam along a narrow, tortuous channel. The flood height when it reaches the village of Hattian may not be significantly lower than at the breach point.

\section{Mitigation of Flood Hazard Posed by the Landslide Dams}

After visiting the Hattian Bala landslide dam with geotechnical and hydraulic engineers from the Pakistan Military Engineers and discussing the possibilities regarding the construction of spillways in the landslide debris damming the lakes in the Karli and Tang drainages, we concluded that the landslide debris is composed of sufficient fine-grained debris to be unstable as water flows across it during a dam breach once the reservoirs overtop the landslide dam. It was deemed necessary to excavate a spillway across the debris dam within the Karli stream drainage to allow overflow of the reservoir before it filled to its maximum elevation and lake volume. This would reduce the volume of the reservoir from its maximum volume and its hydraulic head so that a less severe flood would be likely in case the breach of

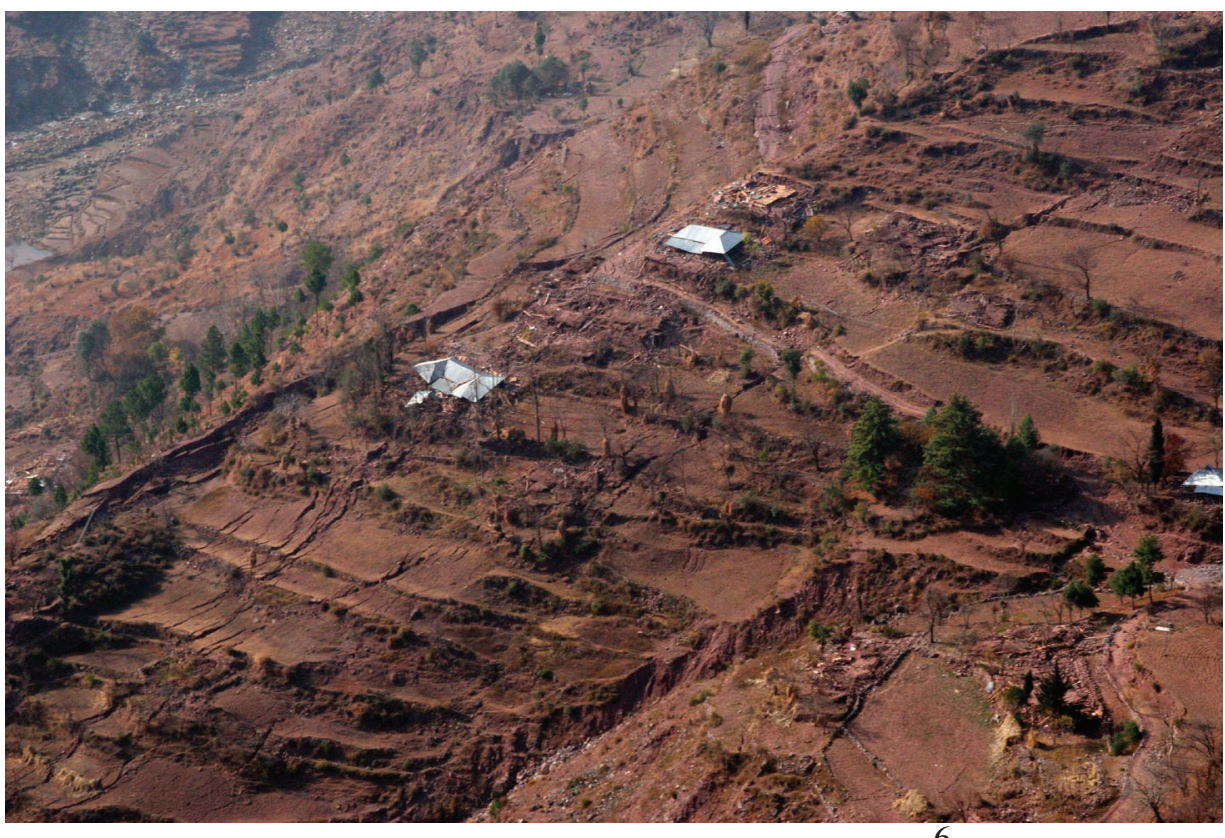

Figure 5. Oblique aerial view of slopes above the reservoir in the Karli stream drainage with numerous fractures (lower left in photograph) extending through the terrain parallel to the slope direction and to the strike of bedding. 


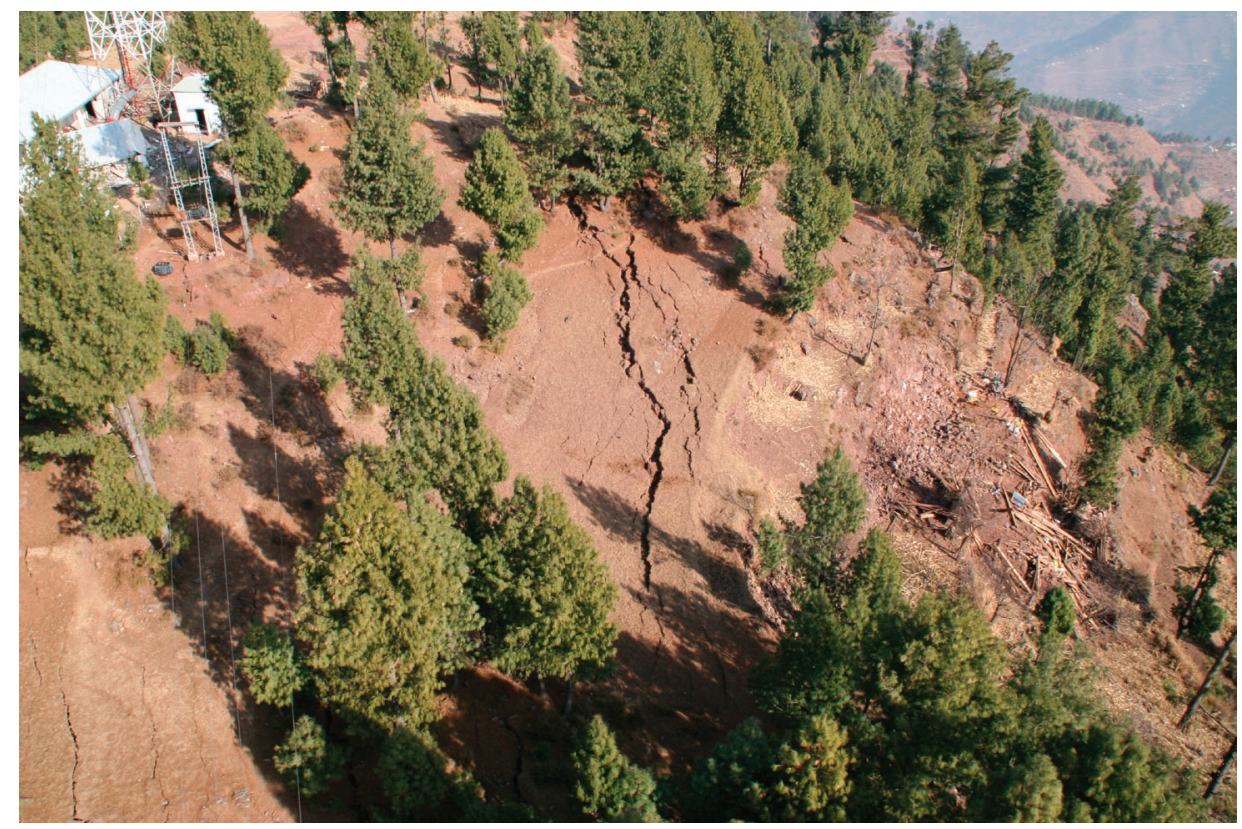

Figure 6. Fractures on ridgetop (Dana Hill) above debris avalanche.

the landslide dam is rapid or catastrophic. The volume of the reservoir in the Tang stream drainage was initially not considered sufficient to warrant constructing a spillway to reduce its volume before breaching.

The engineers concluded that enough width exists at the lowelevation saddle in the debris blocking the Karli drainage to excavate a spillway $30 \mathrm{~m}$ deep (fig. 7). A spillway $100 \mathrm{~m}$ deep, sufficient to reach the current lake level, is not possible because the excavated slopes would have to be too steep to be stable. The saddle where the spillway will be excavated is approximately $200 \mathrm{~m}$ wide with gentle slopes. The mixture of fine-grained and boulder-sized debris indicates that some blasting of large rocks will be necessary in the excavation process. The westernmost part of the saddle is less than $100 \mathrm{~m}$ wide parallel to the stream drainage with moderately steep slopes in the debris to the north where much of the excavated debris could be sidecast (fig. 8).

The smaller reservoir in the Tang drainage had only 10-20 m of freeboard as of December 19, 2005. The military task force constructing a road into the area arrived there on December 19, 2005. This reservoir has subsequently been breached (March 2006) by the military task force, and the breaching of this reservoir has not affected the overall stability of the landslide debris. At 1,500 acre-feet, the lake in the Tang drainage was 10 percent of the size of the larger lake in the Karli drainage, but still produced enough of a flood at breaching to require evacuation of people living downstream near stream level.

A consensus was reached that excavating a spillway in the Karli dam blockage is a reasonable method of mitigating the hazard and that a spillway $30 \mathrm{~m}$ lower than the present low point of the landslide dam is feasible. Even if a spillway is successfully constructed in the landslide-dam material, the lake level in the Karli drainage will be in excess of $90 \mathrm{~m}$. This will still cause a significant flood if the breaching process is sudden. A catastrophic breach of the dam material is likely to produce flooding that will endanger most of the residents who live in and near the village of Hattian, $2.8 \mathrm{~km}$ downstream. Due to the narrow and winding nature of the canyon downstream from the landslide dam, the initial flood height after breaching is not likely to be significantly dissipated by the time it reaches Hattian.

\section{Downstream Populations}

The nearest settlement downstream from the landslide dam is the village of Hattian, which is $2.8 \mathrm{~km}$ distant and is at the junction of the Jhelum River and the Karli tributary dammed by the landslide. The stream course downstream from the landslide dam is a steep, narrow canyon with numerous tight meanders and associated narrow ridges that bisect the inside curves of these meanders. Dwellings near the stream course are high on the slopes above the stream except near the outskirts of Hattian. Here, within one kilometer of the village, there are a few dwellings located near the stream and not far above it. As the stream course reaches Hattian, it curves to the left in a tight meander with the main body of Hattian on the right. At this point, numerous permanent and temporary shelters are located near the stream and only slightly above it. A bridge over the stream, part of the highway along the Jhelum River that leads to India, is just beyond this meander (fig. 9).

If the dam blocking the Karli stream drainage breaches catastrophically, floodwaters and mixed sediment traveling downstream from the breach will superelevate at the junction with the Jhelum River and will tend to be carried by centrifugal force toward the center of Hattian village. The village is located on an uplifted river terrace that slopes down to the tributary stream where it joins the Jhelum River. This slope forms a smooth ramp that will enhance the runup on the outside of the meander in the direction of the main portion of the village (fig. 10). Downstream from Hattian, along the Jhelum River, 


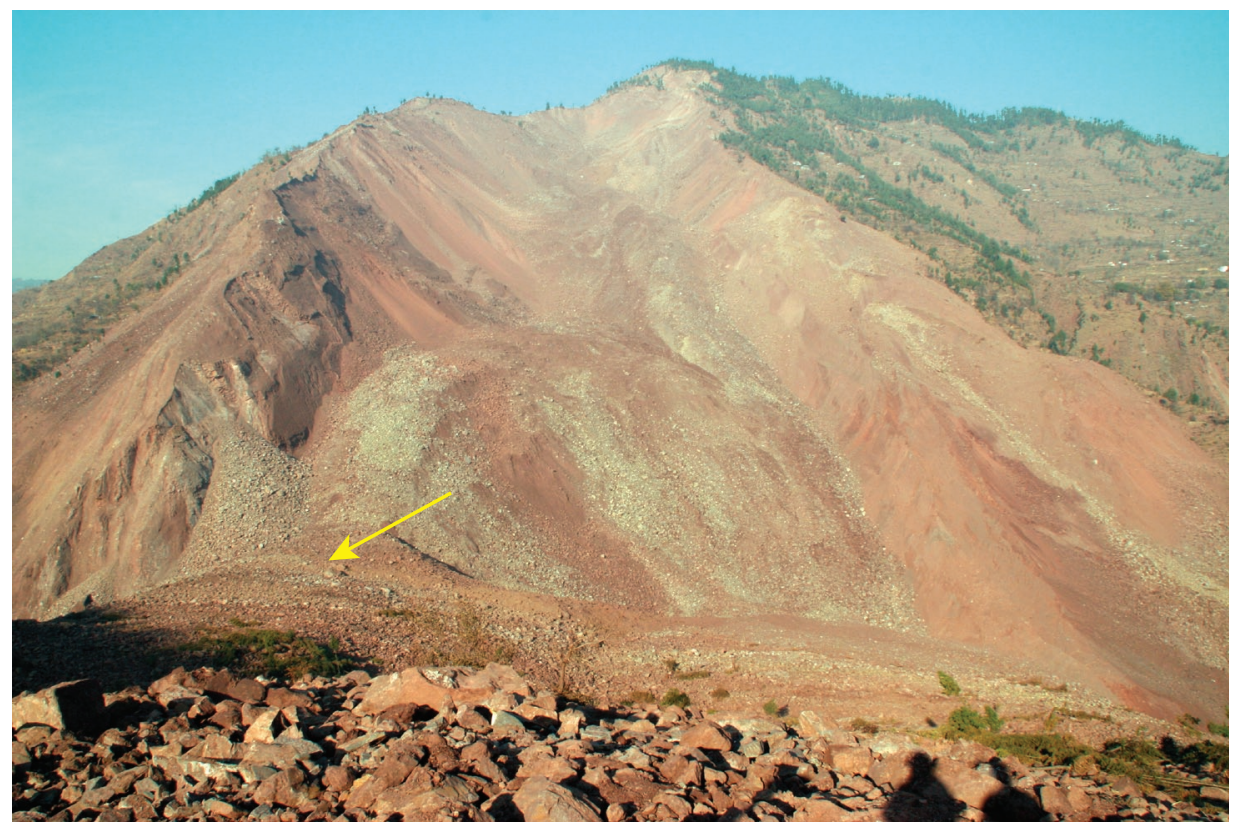

Figure 7. Ground view of debris avalanche and Karli stream debris dam with arrow pointing to low point at the crest where a spillway is to be excavated.

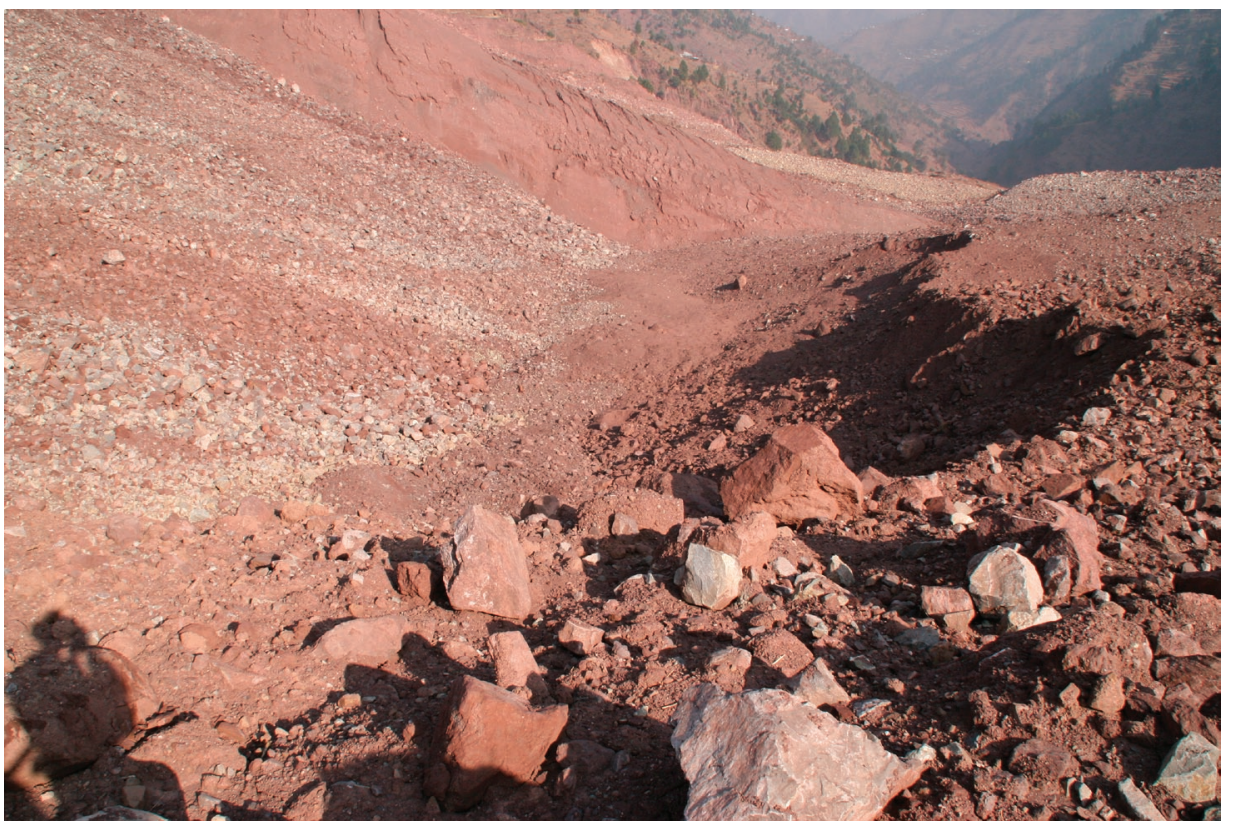

Figure 8. View northeast downvalley from crest of the Karli stream landslide dam where Pakistan military engineers plan to construct a spillway in the debris. Note the depression in the foreground where some of the excavated debris may be deposited. 


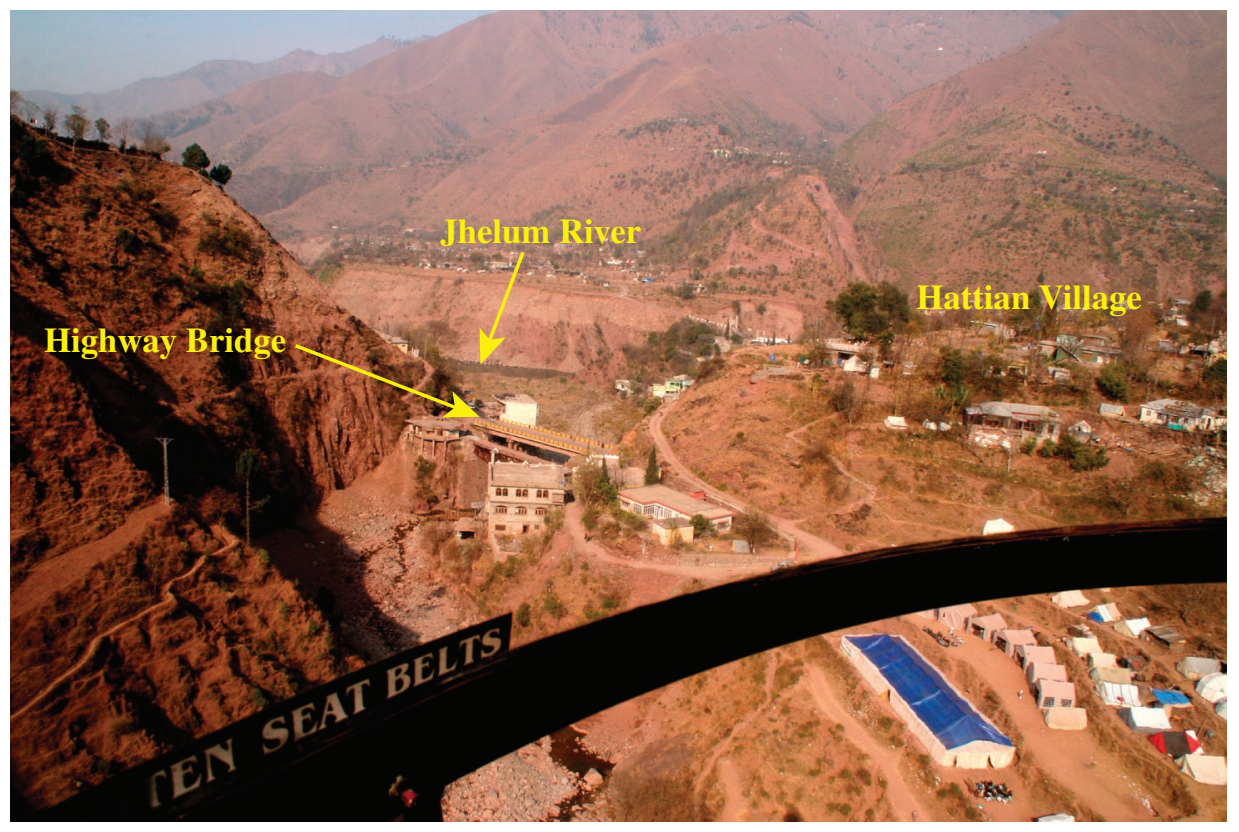

Figure 9. Northward aerial view of village of Hattian showing bridge on main highway to India and other permanent and temporary dwellings near stream level of the landslide-dammed Karli tributary to the Jhelum River.

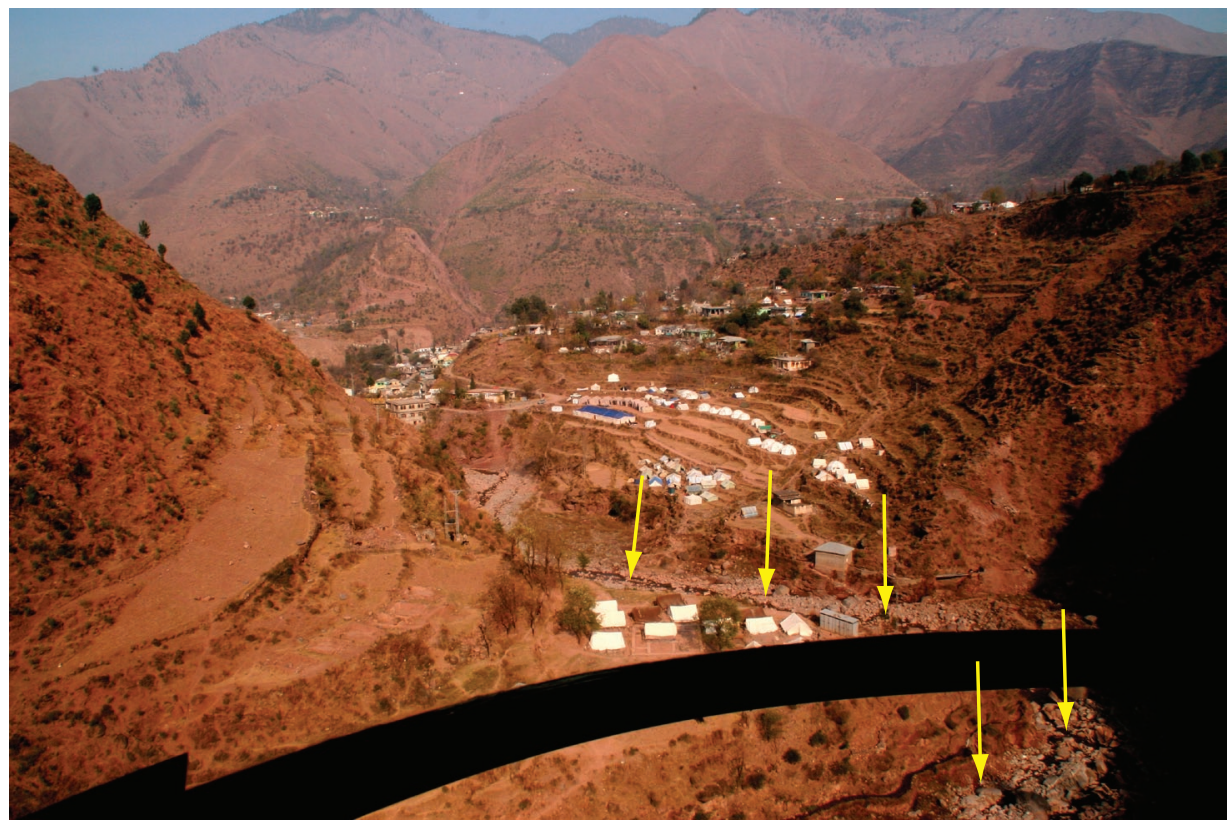

Figure 10. Aerial view of tributary stream drainage near Hattian. Location of tent camp in middle ground is on a smooth ramp just above the tributary stream (arrows) whose channel is curving to the left. This area is likely to be subject to severe runup, or superelevation, of floodflow immediately following a potential breach of the Karli stream landslide dam. 
above the river. To adequately evacuate these populations prior to the breach of the Hattian Bala landslide dam by the Karli stream, flood-routing models appropriate to the conditions of the landslide deposits with an excavated spillway have been run to estimate the extent of evacuation necessary. This information is currently being evaluated by the Pakistan military.

\section{Summary}

The Hattian Bala debris avalanche triggered by the October 8 , 2005 earthquake contains approximately 80 million cubic meters of sandstone, siltstone, mudstone, clay shale, and limestone debris from the Miocene Murree Formation (Calkins and others, 1975). The avalanche dammed the Karli and Tang tributaries of the Jhelum River at a point $32 \mathrm{~km}$ southeast of the city of Muzafarrabad. The debris dam filled the Karli drainage to a maximum depth of approximately $130 \mathrm{~m}$ and occupies $1.3 \mathrm{~km}$ of that stream course. The landslide debris contains over 50 percent by volume of sediment in sizes ranging from cobble to clay, sizes that will be readily eroded as the reservoirs overtop the landslide dam. This is likely to result in rapid enough erosion rates to cause flash flooding during a breach of the landslide dam by the reservoirs and present a hazard to downstream populations. Scientists from both the National Weather Service and the U.S. Geological Survey have assembled data and have run computer models to estimate the reach and heights of downstream flooding from the breach of the landslide dam from various scenarios that include the natural breach and that with an excavated spillway constructed at a level $30 \mathrm{~m}$ below the natural spillway low point on the dam crest.

\section{Acknowledgements}

The Disaster Assessment Response Team (DART) of the U.S. Agency for International Development (USAID) in Islamabad provided logistic and communication support during the visit. Major General Shahid, Brigadier General Nasrullah Abeer, and Brigadier General Aftab Sadiq of the Pakistan
Military Engineers, and Tahir Hayat of National Engineering Services Pakistan (PVT) Limited provided helicopter and other logistical support to the field to inspect the landslide and debris dam. They also provided data and consultation with field engineers so that valuable information could be transferred to those preparing digital elevation models and other critical data for the landslide dam-breach analysis.

\section{References Cited}

Calkins, J.A., Offield, T.W., Abdulla, S.K.M., and Ali, T., 1975, Geology of the southern Himalaya in Hazara, Pakistan, and adjacent areas: U.S. Geological Survey Professional Paper, v. 716-C, p. 1-29.

Sato, H.P., Koarai, M., Une, H., Hasegawa, H., Iwahashi, J., Kamiya, I., and Ishitsuka, Y., 2006, Interpretation of landslide distribution triggered by the Northern Pakistan earthquake on 8 October 2005 using 2.5-m-resolution SPOT 5 stereo imagery: Proceedings of the International Conference on October 8, 2005, earthquake in Pakistan, Islamabad, Pakistan, p.104-106.

Schneider, J.F., 2006, Earthquake triggered mass movements in northern Pakistan with special reference to the Hattian slide: in Kausar, A.B., Karim, T., and Khan, T., eds., Proceedings of the International Conference on October 8, 2005 , earthquake in Pakistan, Islamabad, Pakistan, January 18-19, 2006, Islamabad, Pakistan, Geological Survey of Pakistan, p. 76-78.

Varnes, D.J., 1978, Slope movement types and processes, in Schuster, R.L., and Krizek, R.J., eds., Landslides-Analysis and Control, Transportation research Board, National Academy of Science, Special Report 176, p. 11-33. 